\title{
RECENT COASTAL EVOLUTION OF THE DOÑANA NATIONAL PARK (SW SPAIN)
}

\author{
ANTONIO RODRÍGUEZ-RAMÍREZ,* JOAQUÍN RODRÍGUEZ-VIDAL,* LUIS CÁCERES, * LUIS \\ CLEMENTE, $\dagger$ GIORGIO BELLUOMINI, $\ddagger$ LUIGIA MANFRA, $\$$ SALVATORE IMPROTAI and \\ JOSÉ RAMÓN DE ANDRÉS** \\ * Departamento de Geología, Universidad de Huelva, Campus de La Rábida, 21819 Palos de la Frontera, \\ Huelva, Spain \\ $\dagger$ Instituto de Recursos Naturales y Agrobiologia (CSIC). Apartado 1052, 41080 Sevilla, Spain \\ +Centro di Studio per il Quaternario e l'Evoluzione Ambientale del CNR, Dipartimento di Scienze della Terra, \\ Università 'La Sapienza', O0185 Roma, Italy \\ \$Dipartimento di Scienze della Terra, Università 'La Sapienza', O0185 Roma, Italy \\ IIDipartimento di Fisica, Università 'La Sapienza', 00185 Roma, Italy \\ **Instituto Tecnológico y Geominero de España, Ríos Rosas, 23, 28003 Madrid, Spain
}

\begin{abstract}
Since the last Holocene sea level rise, about $6900 \mathrm{BP}$, a series of depositional littoral landforms has been generated at the outlet of the Guadalquivir River, with progradation along the predominant longshore drift (towards the east).

The first coastal progradation occurred between 6900 and 4500 BP. The Donana and (perhaps) La Algaida spits, both associated with the oldest and highest marshland in the Donana National Park, are assumed to have been developed at an early stage. Originally, the Guadalquivir estuary was wider and deeper than now, and its environment was mainly marine.

The oldest littoral formations have been dated as ca. $4735 \mathrm{BP}$. They show erosional events, and indicate the breaking-up of earlier spit-barriers to form inlets. The marine environment became increasingly dominant, with heavy erosion of cliffs and a retreating coastline.

This period was followed by another sedimentary cycle $(4200-2600 \mathrm{BP})$ that surrounded the earlier eroded barriers. The size of the estuary decreased due to the increasing marsh deposits, and a fluvial environment was born.

About 2600 years ago, progradation gave way to a new period of intense erosion. The resulting morphology of littoral strands and erosional surfaces permitted the retum to a marine environment. The shoreline again relreated.

From $2300 \mathrm{BP}$, coastal progradation has prevailed, with an erosional interruption at $1000 \mathrm{BP}$. The present-day outlet of the Guadalquivir is an estuarine delta of inactive marshland (the Donana National Park), the dominant environment is fluvial.
\end{abstract}

\section{INTRODUCTION}

The present-day Iberian south-Atlantic littoral is characterized by a series of broad zones under tidal influence associated with the mouths of the main rivers. These outcts have tended to be sealed by the growth of littoral spits and barrier-islands. In this way, extensive wetlands of great ecological interest have been formed. The most important - for its size and variety - is the Doñana National Park.

Such a coast is the result of various circumstances. Firstly is the rise in sea level following the Last Glacial Age (the Flandrian transgression), which reached a maximum in this sector around $6500 \mathrm{BP}$ (Zazo et al, 1994). The domination by the marine environment meant the invasion of the low part - the river valleys
- to form estuaries and bays, and the configuration of the interfluvial areas as coastal projections (promontories and capes) on which cliffs were formed. Secondly, after the transgression maximum the agents modelling this coastal sector werc dynamic ones such as Jongshorc drift, tide, and wind. They were aided by the labile, Neogene and Quaternary sandy substratum. The prevaling longshore drift has been towvards the $\mathrm{E}$ and $\mathrm{SE}$, so that the sandy barriers have been formed in that direction. Drift intensity increases in the Gibraltar Strait region, because of the greater entrance of Allantic water into the Mcditcrranean in anticyclonic periods (the Azores anticyclone). The modelling and filling of the zones protected from the open sea, such as estuaries, is determined by the tide, with additional contribution from fluvial sediments. Lastly, the prevailing SW winds 
TABLE I. Samples and ages in the Guadalquivir outlet area (Atlantic coast. SW Spain)

\begin{tabular}{|c|c|c|c|c|}
\hline Lotation & Sample & $\begin{array}{l}\text { "C Conventional age } \\
\text { (BP) }\end{array}$ & $\begin{array}{l}{ }^{14} \mathrm{C} \text { Calibrated age } \\
(95 \%)\end{array}$ & $\begin{array}{l}\text { Age } \\
\text { (BP) }\end{array}$ \\
\hline \multirow[t]{10}{*}{ Doñana } & $\mathrm{R}-2205^{1}$ & $2185 \pm 50$ & 80 A D -270 A.D. & 1775 \\
\hline & $\mathrm{R}-2185^{1}$ & $1860 \pm 50$ & 440 A.D. -655 A.D. & 1402 \\
\hline & $\mathrm{R}-2210^{\mathrm{I}}$ & $2010 \pm 50$ & 270 A.D. -470 A.D. & 1580 \\
\hline & $R-2204^{l}$ & $1400 \pm 50$ & 830 A.D. -1020 A.D. & 1025 \\
\hline & $R-2] 87^{1}$ & $1790 \pm 50$ & 530 A.D. -700 A.D. & 1335 \\
\hline & $\mathrm{R} \cdot 2188^{\prime}$ & $1850 \pm 50$ & 140 A.D. -660 A.D. & 1400 \\
\hline & $\mathrm{R}-2271$ & $2641 \pm 47$ & 392 B.C. -339 B.C. & 2315 \\
\hline & $R-3282$ & $1620+34$ & 736 A.D. -815 A.D. & 1175 \\
\hline & R-2286 & 1353131 & I,028 A.D, 1,069 A.D. & 902 \\
\hline & $R-2287$ & $1518 \pm 36$ & 859 A.D. -948 A.D & 1047 \\
\hline \multirow[t]{9}{*}{ La Algaida } & $\mathrm{R}-2262$ & $1865 \pm 35$ & 530 A.D. -608 A.D. & 1380 \\
\hline & $R-2263$ & $1800 \pm 40$ & 591 A.D. -662 A.D. & 1325 \\
\hline & $\mathrm{R}-2272$ & $1972 \pm 40$ & 400 A.D. -475 A.D. & 1515 \\
\hline & $\mathrm{R}-2284$ & $2233 \pm 29$ & 93 A.D. -158 A.D. & 1825 \\
\hline & $B-88018^{2}$ & $1600+60$ & $1222 \mathrm{BP}-1071 \mathrm{BP}$ & 11.46 \\
\hline & $B-88019^{2}$ & $1340 \pm 60$ & $931 \mathrm{BP}-804 \mathrm{BP}$ & 867 \\
\hline & $\mathrm{B}-88020^{3}$ & $1.150+70$ & $1055 \mathrm{BP}-918 \mathrm{BP}$ & 986 \\
\hline & $B-88021^{2}$ & $1530 \pm 70$ & $1153 \mathrm{BP}-978 \mathrm{BP}$ & 1065 \\
\hline & $B-88022^{2}$ & $2487 \pm 70$ & $2487 \mathrm{BP} 2322 \mathrm{BP}$ & 2404 \\
\hline Carrizosa-V. la Arena & $\mathrm{R}-2273$ & $4548+59$ & 2870 B.C. -2697 B.C. & 4735 \\
\hline \multirow[t]{2}{*}{ Vetalengua } & $\mathrm{R}-2283$ & $2171 \pm 36$ & 147 A.D. -248 A.D. & 1753 \\
\hline & $B-88016^{2}$ & $2230+60$ & $1879 \mathrm{BP}-1738 \mathrm{BP}^{2}$ & 1808 \\
\hline \multirow[t]{4}{*}{ Marsh strand } & $\mathrm{R}-2278$ & 2284139 & 28 A.D. -119 A.D. & 1877 \\
\hline & $\mathrm{K}-2279$ & 3679 上 48 & 1680 B.C. -1553 B.C. & 3567 \\
\hline & $\mathrm{R}-2280$ & $3694 \pm 61$ & 1716 B.C. -1562 B.C. & 3589 \\
\hline & $B-88017^{2}$ & $3460+90$ & $3421 \mathrm{BP}-3219 \mathrm{BP}$ & 3320 \\
\hline
\end{tabular}

Labonatories: Centro di Studio per al Quaternario e l Evoluzione Ambientale del CNR-Dipartimento Scicme defla Terra, Universià 'La Sapienza' (Roma, laly).

Zazo et al. (1994). Beta Analytic Inc, Miami, FL. USA.

have helped (and continue to help) the development of dune fields systems.

Study of the different, most recent (Holocene) sedimentary bodies of the south-Iberian littoral has distinguished four main cycles of coastal progradation (Zazo et al., 1994): $\mathrm{H}_{1}$ from 6900 to $4000 \mathrm{BP} ; \mathrm{H}_{2}$ from 4000 to $2500 \mathrm{BP} ; \mathrm{H}_{3}$ from 2500 to $1000 \mathrm{BP}$; and $\mathrm{H}_{4}$ from $1000 \mathrm{BP}$ to the present. These periods are separated by shorter ones of no progradation or erosion.

This work aims to establish the space-time evolution of the Donana National Park and its surroundings during the last millennia, and to determine the possible modifications of the different factors affecting it, such as climate, marine dynamics, and variations in sea level. To these must be added anthropogenic activity of some hundreds of years. Detailed geomorphological mapping has been used to make morphosedimentary analysis and both calibrated (amino acids and ${ }^{14} \mathrm{C}$, see Table 1) and archaeological datings.

Geomorphologieally, the present-day Doñana National Park and its surroundings comprise three morphogenic systems: littoral, estuarine, and acolian (Fig. 1). The littoral system is formed by the various spits and sandy strands that tend to seal off the Guadalquivir estuary. On the right bank is the Donana spit. This comprises the most extensive system of spits, which has grown towards the $\mathrm{E}$ and SE. They are partly covered today by active dunes. On the left bank is La Algaida spit, which has grown towards the NNE.

The estuarine system comprises the marshes filling the extensive area behind the littoral spits. This filling has taken place gradually as the littoral formations have sealed the estuary. Thus there is a direct relationship between the littoral formations and the estuarine ones. The marshes include various morphologies, as a result of the intense fluvial action.

The aeolian system comprises the dune fields, extensive both continentally and littorally. Geomorphological mapping reveals five sequences of dunes: the three oluest are stable and inland, occupying a considerable area, while the two more recent ones are coastal, of smaller area, and frequently overlapping. They are the most distinctive dune complexes, and include the active dune systems, covering the most recent littoral formations.

The three oldest dune fields (phases I-III, Fig. I) have a light grey to yellowish colour, 10YR7/2 to 10YR7/8, and the two recent ones have a pale brown colour, 10YR7/4 (after Siljeström, 1985). 


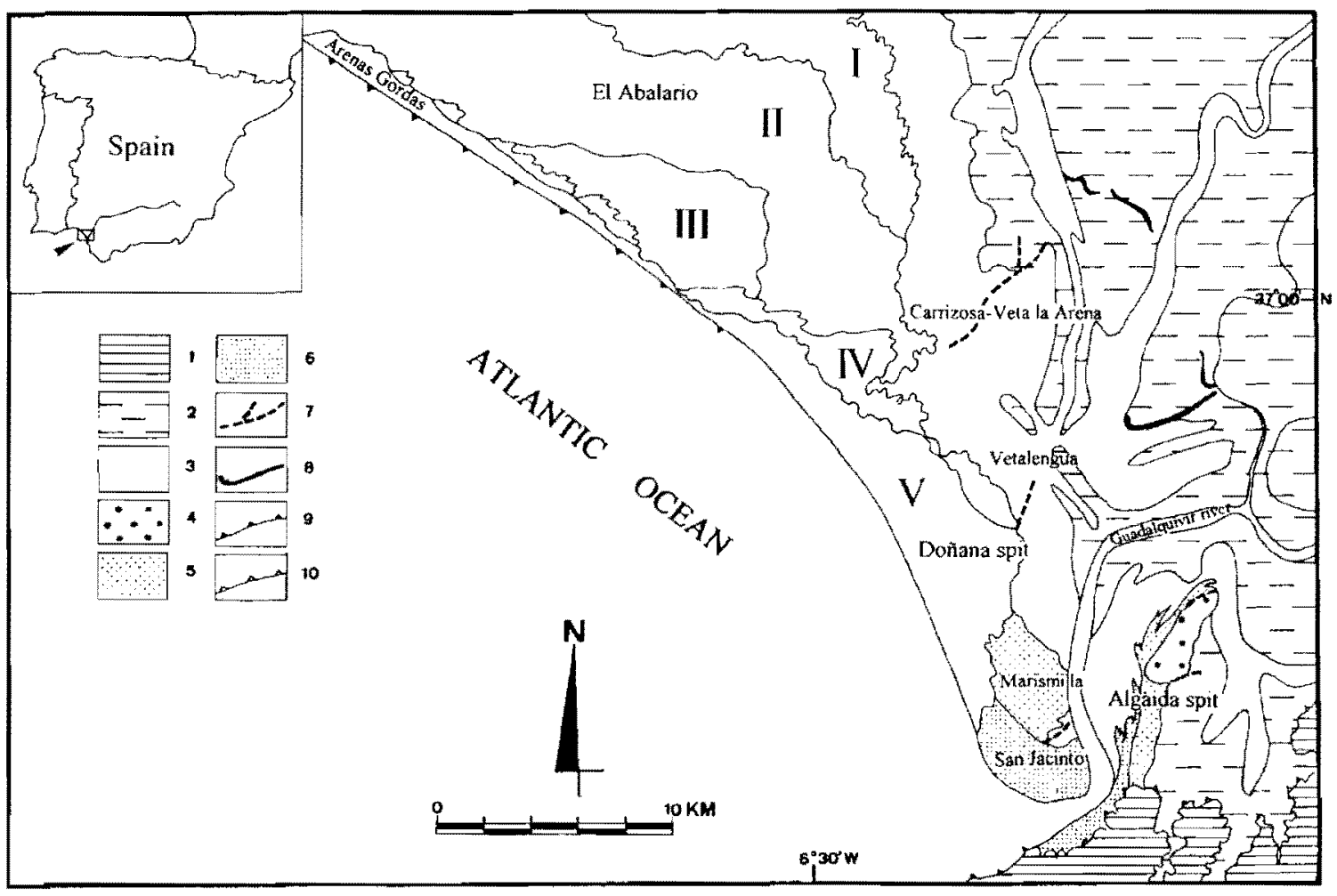

FIG. 1. Gcographical location and geomorphological synthesis of the Guadalquivir outlet area. I.-V: Sequences of Holocenc dunes. 1. Neogene substratum, 2. Marshland, 3. Saltmarsh, 4. Second progradation phase, 5. Third progradation phase, 6. Fourth progradation phase, 7. Erosional strands, 8. Marsh strands, 9. Active clifs, 10. Inactive cliffs.

\section{COASTAL MORPHOLOGY AT THE TRANSGRESSION MAXIMUM}

The rapid rise in sca level following the final phase of the Last Glacial Maximum caused a rapid and marked coastal retreat along the whole of this sector of the Iberian South-Atlantic coast. Lower rates of rise during this period generated deposits of peat (such as that found at a depth of $25 \mathrm{~m}$ in Cádiz Bay), between $9495 \pm 340$ and $8915 \pm 100$ BP (Dabrio et al., 1995).

The lower valley of the Guadalquivir - the most important river of the region - was transformed into a wide estuary, and the coastal promontories and flanking headlands were eroded into cliffs (Fig. $2 \mathrm{~A}$ ).

Coastline retreat was helped by a topography of gentle slopes and a bare shore formed basically of weakly. cemented Neogene and Quaternary sands. Detritus became highly available, and was transported along the whole coast, to be deposited mainly in cstuaries, dunes and submerged parts of the continental platform.

The high rates of coastal erosion and the intense supply of fluvial detritus helped to continentalize the Guadalquivir estuary. The present-day estuary is filled with sediments and the river flows sluggishly. The extensive tidal flats of the Doñana National Park are the result of gradual accretion and withdrawal of the marsh during the last 6900 years, with the consequent reduction in the estuary area.

To the west of the present-day mouth of the
Guadalquivir (Fig. 1), complex systems of transgressive dunes have formed along almost $60 \mathrm{~km}$ of coastline. migrating inland as the coastline retreats. Geomorphological cartography at regional level has enabled three ancient stable aeolian systems to be distinguished. Their direction of displacement indicates a prevailing WSW wind.

\section{FIRST PROGRADATION PHASE}

The activity following the transgression maximum, helped by the relative stability of the sea level, gave rise to a series of progradation phases, tending to make the coastal profile uniform, followed by erosion. Thus the estuarine inlets were filled or sealed and the promontories were eroded.

The oldest evidence of the beginning of coastal progradation in this Iberian South-Atlantic sector comes from the first peat deposits that accumulated in the main lagoons (such as the lagoon of Las Madres) from $5536 \mathrm{BP}$ (Menéndez and Florschütz, 1964). These show that the coastal profile was already becoming uniform, with littoral barriers closing off the inlets. This was particularly so in the rivulet valleys, which were converted into littoral lagoons. Many of these first deposits of peat have been eroded by coastal retreat.

Pollen analysis of these peat levels (Freijeiro and Rothemberg, 1981; Stevenson, 1984) reveals temperate- 


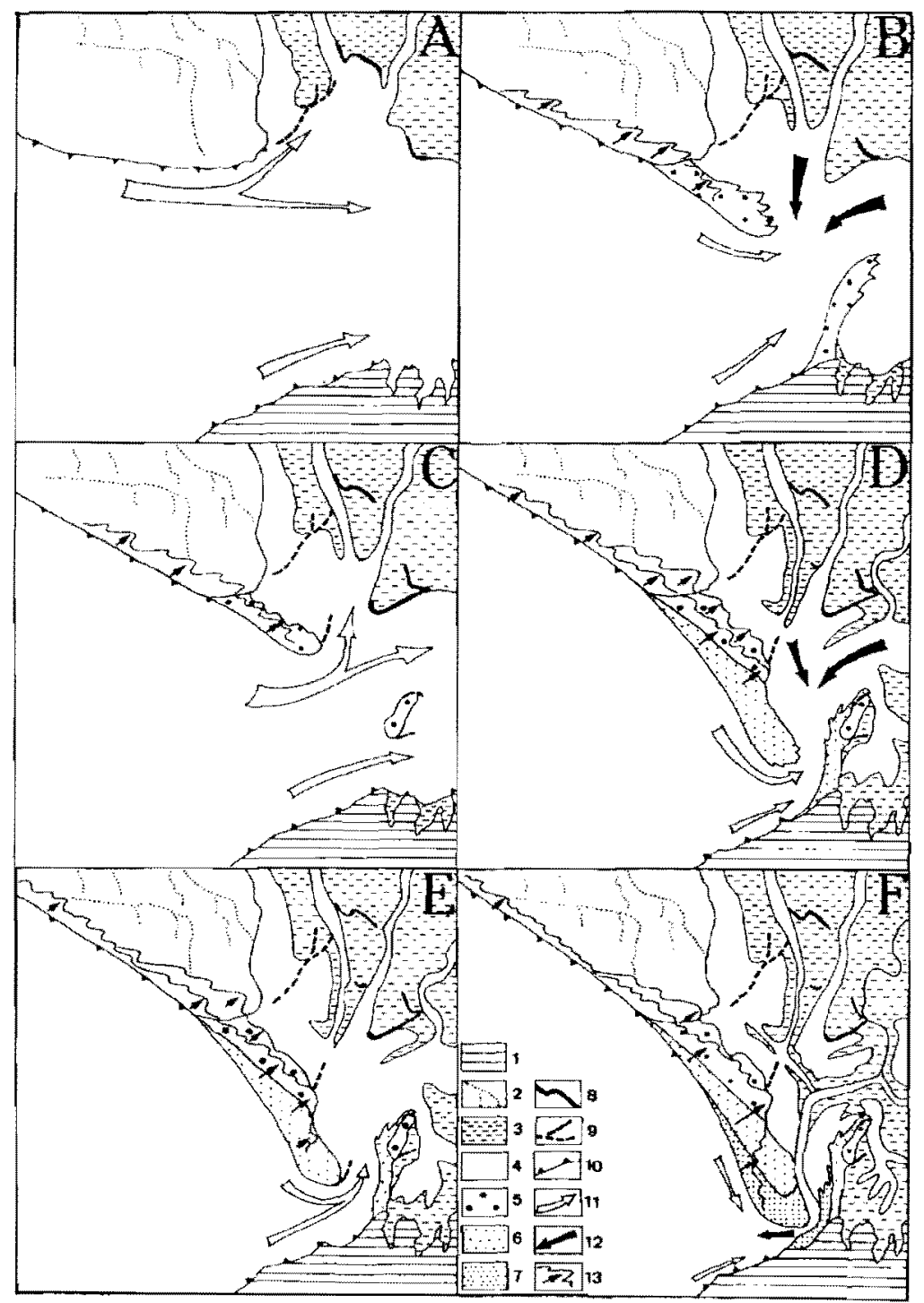

FIG. 2. Evolutive sequence of the Guadalquivir oullet area (Donana National Park): A. First erosional event, B. Second progradation phase. C. Second erosional event. D. Third progradation phase. E. Third erosional event, F. Fourth progradation phase. Legend: 1. Neogene substratum, 2. Ancient aeolian system (phases I-III), 3. Saltmarsh, 4, Mudflat, 5 . Second progradation phase, 6. Third progradation phase, 7. Fourth progradation phase, 8. Marsh strands, 9. Erosional strands, 10. Cliffs, 11. Marine streams, 12. Fluvial streams, 13. Recent aeolian system (phases IV-V).

wet palaeoclimatic conditions, between Atlantic and Subboreal episodes.

In the area occupied by the present-day mouth of the Guadalquivir, the oldest littoral formations (detectable by geomorphological mapping) are the Carrizosa-Veta la Arena strands (Figs 1 and 2A). Aminoacid and ${ }^{14} \mathrm{C}$ dating of shells gives a calibrated age of $4735 \mathrm{BP}$. The real age may be somewhat lower (because of possible removing of the sample), which would place it within the first erosional event ( $4000 \mathrm{BP}$ ) defined by Zazo et al. (1994) for southern Spain.

The geomorphological arrangement of these littoral formations (perpendicular to the direction of the main barriers) and their small size are evidence of a short-lived but highly intense erosional event that destroyed an earlier sandy barrier.

The main direction of progradation was towards the NE - that is, into the estuary. The formations are supported laterally on earlier marshland deposits, at a height of +2 $\mathrm{m}$, showing the palaeocoastline and giving a slight increase in above-sea-level height.

At a regional level, the first phase of progradation deposits was between 6900 and $4000 \mathrm{BP}$ (phase $\mathrm{H}_{1}$ of $\mathrm{Zazo}$ et al., 1994). In the Guadalquivir mouth, this episode has been eroded; its remains can be found below the transgressive aeolian formations in the zone of El Abalario. The root zone of this tirst littoral spit was located on the west side of the outlet, on a coastal headland, today eroded. The direction of advance was towards the ESE. 


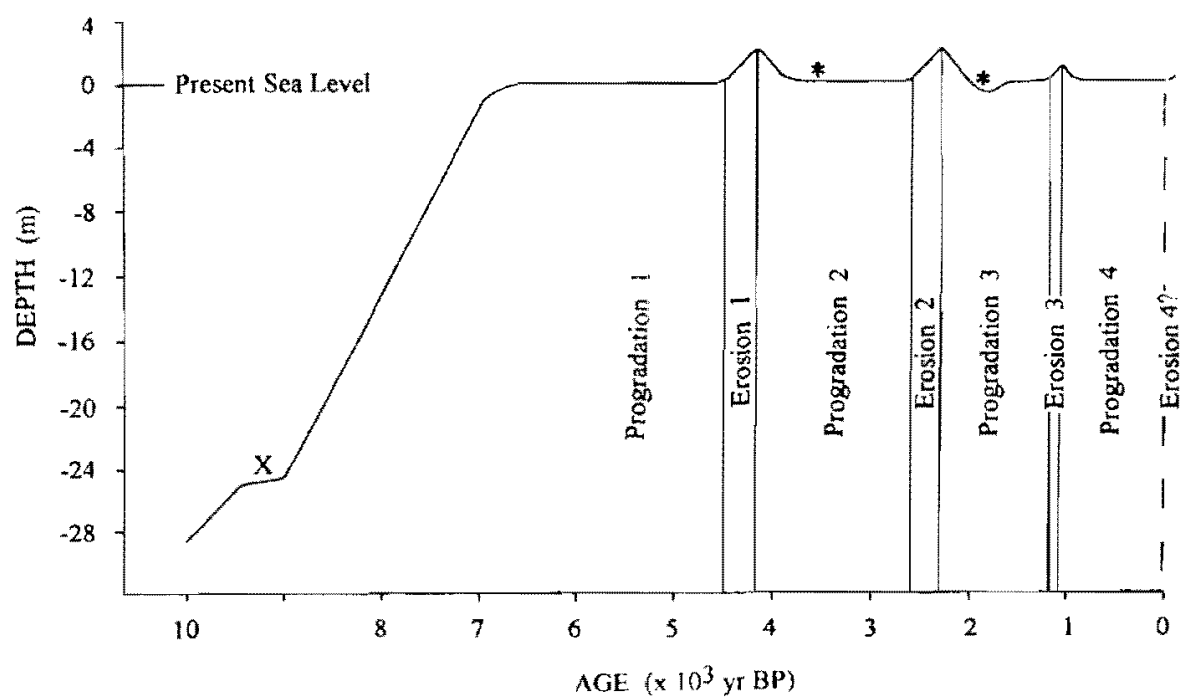

FIG. 3. Regional curve of relative sea-level changes during the last 10,000 years, derived from the positions and morphologies of the associated sedimentary bodies. (*) Biological crises, (X) Sea-level position about Dabrio et al. (1995).

\section{SECOND PROGRADATION PHASE.}

This phase, which isolated the Guadalquivir estuary from the sea, led to a decreased marine influence in its interior, and a dominant continental environment (Fig. 2B). Filling of the estuary was helped by small, fingered delta bodies (like a birds-foot) in the main affluents.

The fluvial dominance provoked a marked biological crisis in the marine fauna (Fig. 3), with considerable accumulations of organic remains at the sides of the palaeoestuary. Such shell deposit remains have been dated as from ca. 3567-3589 BP. This marks the moment of the environmental crisis and the progradation of the littoral barriers, so reducing the openings communicating the sea with the estuary.

On the right side of the Guadalquivir mouth (Doñana littoral spit), the remains of this progradation phase are very eroded by fluvial action, and are hidden below the sheets of active dunes that advance towards the NE. These active dunes (fourth aeolian system) are associated with this second progradation phase.

On the lcft side, the first vestiges of deposits that could be determined cartographically are located on La Algaida spit. On them have been found pre-Roman scttlements and archaeological remains of the VIIth to IInd centuries B.C. (Menanteau, 1979).

The morphological features of this littoral spit indicate that there was progradation towards the NE, but it is not possible to deternine whether there was union with the continent at that time or not; that is, we are not sure whether morphologically it was a spit or an island.

The headlands situated on either flank of the Guadalquivir outlet must originally have been more prominent, and their erosion and consequent retreat were linked to this second progradation phase.

In the sandy formations of both the right and left banks, this progradation phase is intcrupted by an erosional event, with a height above sea level of around $+2 \mathrm{~m}$. This event resulted in a greater estuarine domination within the marsh, with a new coastline being defined in the marine inlet and the development of characteristic fauna, especially of the genus Cerastoderma.

In the area of the Doñana National Park, this rupture is seen in the Vetalengua strands (Figs 1 and 2C), which advanced towards the NNE. A similar phenomenon was produced on La Algaida spit, with the erosion of the earlier sandy formation leaving an island of oval shape surrounded by two arms of sea - one very wide (some 6 $\mathrm{km}$ ) between Doñana and La Algaida, and the other, smaller, between the latter and the continent.

Estrabón in his work Geographica, written between 29 and 7 B.C., speaks of this estuary as an inland lagoon, which he called Lacus Ligustinus, with a double outlet to the sea. Between the two channels was an island where, according to oral tradition, there was a city with the same name as the river - Tartessos. Despite these historical references, the data do not enable a sure estimate of the beginning of this erosional event. The only dating made on the Vetalengua strands gives a date of ca. $1753 \mathrm{BP}$, which is probably of a later point in its evolution. At regional level, Rodríguez-Vidal (1987) and Zazo et al. (1994) date this event around 2500-2000 BP and $2500 \mathrm{BP}$ respectively.

\section{THIRD PROGRADATION PHASE}

This new progradation phase rcsulted in a considerable growth of the littoral and aeolian formations, a retreat of the cliffs, and the gradual sealing of the Guadalquivir estuary (Fig. 2D). The decrease in size of the mouth of the old Roman estuary (Lacus Ligustinus) holped to increase the Ruvial influence. The Guadalquivir delta extended within the estuary by surface fingers of the delta system, causing a new crisis of the fauna adapted to the salt-water 
medium (Fig. 3). Accumulations of organic remains mainly of the genus Cerastoderma - - can be found at the sides of the palacoestuary. The calibrated age of these is ca. $1877 \mathrm{BP}$, marking the littoral progradation.

In Doñana, this phase gave rise to the strands of La Marismilla, with a direction of progradation towards the SSE. This sedimentary episode shows a marked alternation between ridges and runnels, with a greatest age of ca. $1870 \mathrm{BP}$ and an estimated periodicity in the growth of each ridge of 100 years (Zazo et al., 1994).

In La Algaida, this phase is shown by a series of ridges and runnels oriented towards the NE, engulfing the older sedimentary body. Its calibrated age is 2404 BP. Its morphological configuration changed from that of an island to that of a spit joined to the continent.

At the same time, the littoral strands of La Marismilla, on the other side of the mouth. grew rapidly, causing a decrease of sedimentation on La Algaida. This spit thus became isolated from marine action, completely losing its functionality within the estuary. Since then, it has been surrounded by teposits from the marsh.

It must be remembered that the dating of the sandy formations of La Algaida and Doñana was not made from the oldest beach ridges. Thus it can be assumed that the beginning of progradation is earlier than the dates given. At regional level, Zazo et al. (1994) estimate this to be from $2500 \mathrm{BP}$.

A little further to the west of this coastal sector, the present-day beach situated in front of Las Madres lagoon contains levels of peat (Cáceres, 1995) at $-0.5 \mathrm{~m}$ in depth, aged between $1900 \pm 180$ and $1790 \pm 180 \mathrm{BP}$. Thus the coastline was more advanced and the sea level lower than at present (from $-0.5 \mathrm{~m}$ to $-1.0 \mathrm{~m}$, rig. 3 ).

This third progradation phase is also characterized by very important dune systems, whose activity continued until the later phase. This resulted in the beginning of the genesis of the fifth acolian systcm (Fig. 1), which has lasted until the present. It comprises sandy constructions of great morphological importance, extending geographically from Arenas Gordas to Doniana. In Arenas Gordas, the dunes overlap, with breadths of up to $100 \mathrm{~m}$, showing the maximum cliff retreat in this sector. Four main aeolian cpisodes of parabolic dunes have been differentiated cartographically. Their axes of symmetry indicate the prevailing wind direction at the time. Statistical analysis of these directions (Rodríguez-Vidal ef al., 1993) reveals a gradual change - from WSW to SW showing the variations in regional atmospheric circulation.

The sandy formations of this episode were curtailed by a new erosional event (Fig. 2E), shown in Donana by strands which advanced towards the NE and separated the progradation units of La Marismilla and San Jacinto (Fig. 1). Their calibrated age is 1175 BP. On La Algaida spit this event is less obvious, as its deposits are protected inside the estuary, and suffer less from marine action. At regional level, this erosional event took place some 1000 $B P$.

\section{FOURTH PROGRADATION PLASE}

The fourth progradation phase in this coastal sector is related with that established by Zazo et al. (1994) for southern Span (phase $\mathrm{H}_{4}$ ), from $1000 \mathrm{BP}$ to the present. In Donana it is shown in the littoral strands of San Jacinto (Figs I and 2F), accompanied by a considerable aeolian sheet. It secms to have reactivated with greatcr force from the XVIth century, as shown by the last phases of littora] accretion. On I a Algaida spit, the most western hooks are related to this last progradation phase.

The marked coastal retreat of Arenas Gordas continued in this phase, shown by the more recent aeolian accumulations and by the destruction of coastal buildings of the XVIth century (watch-towers). The retreat at Matalascañas can thus be estimated as $170 \mathrm{~m}$ in the last 240 years.

The smoothing of this promontory or coastal headland, situated to the west of Doñana, has moved the erosionalsedimentary point of inflexion towards the east. The erosional processes have extended towards the root of the ancient littural spit of Doñana (first progratation phase). The rate of retreat has been estimated as $200 \mathrm{~m}$ in the last 220 years. The sediments resulting from this erosion have accumulated at the extreme SE, on the San Jacinto strands, which have prograded $180 \mathrm{~m}$.

Today, the longshore drift is becoming stronger, and erosion is increasing at the end of the San Jatinto strands. Hooks are being formed with NE orientation, encroaching into the Guadalquivir channel. This process is similar to that which took place in preceding erosional events, and could be the result of the present-day increase in sea level. Dabrio et al. (1993) estimate, from chronostratigraphic and sedimentological data, a slight rise until 2050 A.D.

\section{CONCLUSIONS}

Changes in coastal relief following the last postglacial increase in sea level have brought about marked environmental changes in all the natural systems of the Iberian south-Atlantic coast. Geomorphological mapping has enabled time relations to be established between the different sedimentary formations and erosional processes. Archacological evidence and calibrated dating of ${ }^{14} \mathrm{C}$ and aminoacids of fossil shells (Table 1) has helped to establish an absolute chronology.

The littoral spit systcms mapped constitute four progradation phases (Fig. 3). The first is dated between the Flandrian maximum (6900 BP) and $4500 \mathrm{BP}$; the second between 4200 and $3900 \mathrm{BP}$ and 2700 and 2600 $\mathrm{BP}$; the third between 2300 and $1100 \mathrm{BP}$; and the fourth between $1000 \mathrm{BP}$ and the present. There were separations of successive erosional phases between 4500 and 4200 BP, 2600 and $2300 \mathrm{BP}$, and 1100 and $1000 \mathrm{BP}$.

Thus, cycles of higher sedimentation are established, with a slight fall and then stability of sea level. Littoral barrier constructions dominate, with the genesis of extensive tidal nats that decrease the size of the estuaries. These sedimentary phases are intertupted by rapid rises in 
sca level lasting from 100 to 300 years, when the previously constructed littoral barriers are eroded. The cliff's retreat, causing migration inland of dunar constructions, with frequent overlapping layers. Marine influence within the estuaries increases.

The Holocene environmental changes that we have been able to show have thus been generated by global changes in atmospheric circulation and sea currents. Today. we are in a dominant anticyclone situation, controlled by the semi-permanent rotation at the Azores. This leads to increased longshore drift, progradation of the sandy barriers, and high rates of sedimentation.

The progradation phases studied developed immediately following a period of relatively high sea level, when stability was lost and there was a slight fall - that is, in the climatic transition from cyclonic to anticyclonic conditions, and above all, under the laller. That time was especially tragic for the salt-water fauna of the estuaries. In the Guadalquivir, biological ctises can be dated around 3550 and $1870 \mathrm{BP}$.

In periods of low atmospheric pressure, the energy of the marine medium was higher, causing slight rises in sea level and a dominant coastal erosion.

\section{ACKNOWLEDGEMENTS}

The authors would like to thank C. Zazo, D. Gorsline and J. Murillo for critical revisions which have led up to this paper. Financial support was provided by Spanish DGICYT Projects PB91-0622-C03-01 and PB94-1090-C03-01. It is a contribution 10 IGCP Project 367.

\section{REFERENCES}

Cáceres, L.M. (1995). Geomorfología del sector occidental de la Depresión del Guadalquivir. Unpublished Ph.D. Thesis, University of Huelva.

Dabrio, C.J., Zazo. C. and Goy, J.L. (1993). Litoral y riesgos geológicos. V Reunión Nacional de Geología Ambiental y Ord. Territ, Murcia.

Dabrio, C.J.. Goy, J.L., Lario, J." Zazo, C., Borja, F. and González, A. (1995). The Guadalete Estuary during the Holocene times (Bay of Cádiz, Spain). Mediterranean and Black Sea Shorelines (INQUA) Newsletter, 17, 1922.

Freijeiro, A and Rothemberg. B. (1981). Exploración Arqueometalárgica de Huelva. Ea. Labor. Huelva.

Menanteau, L. (1979). Les Marismas du Guadalquivir. Exemple de transformation d'un paysage alluvial au cours du Quatemaire récent. These $3 e$ cycle, University of ParisSorbonne.

Menéndez, J. and Florschütz, F. (1964). Resultados del análisis paleobotánico de una capa de turba en las cercanías de Huelva (Andalucía). Estudios Geológicos, 20, 183-186.

Rodríguez-Vidal, J. (1987). Modelo de evolución geomorfológica de la Flecha Litoral de Punta Umbría, Huelva, España. Cuatemario y Geomorfologia, 1, 247-256.

Rodríguez-Vidal, J., Cáceres, I., Rodríguez-Ramírez, A and Clcmente, L. (1993), Coastal dunes and postflandrian shoreline changes. Gulf of Cadiz (SW Spain). Mediterranean and Black Sea Shorelines (INQUA) Newsletter, 15, 12-15.

Siljeström, P. (1985). Gcomorfología y edafogénesis de las arenas del Parque Nacional de Doñana. Unpublished Ph.D. Thesis, University of Sevilla.

Stevenson, A.C. (1984). Studies in the vegetational history of SW Spain. III Palynological investigations at El Asperillo, Huelva. Joumal of Biogeogrophy, 11, 527-551.

Zazo, C., Goy, J.L., Somoza, L., Dabrio, C.I., Belluomini, G., Improta, S., Lario, J., Bardají. T. and Silva, P.G. (1994). Holocene secucnce of sea-level fluctuations in relation to climatic trends in the Atlantic-Mediterranean linkage coast. Journal of Coastal Research, 10,933-945. 